\title{
Impact of School Principal Leadership Style on Performance Management: A Schooling Agenda
}

\author{
Jacob M Selesho \\ Faculty of Management Sciences, Vaal University of Technology, \\ Vanderbijpark, South Africa \\ jacobs@vut.ac.za \\ Atang A Ntisa \\ Faculty of Management Sciences, Vaal University of Technology, \\ Vanderbijlpark, South Africa \\ atang@vut.ac.za
}

\section{Doi:10.5901/mjss.2014.v5n3p211}

\begin{abstract}
Today's changing milieu, challenges organisations on a regular basis to make strategic changes that will keep them up to date with the transforming atmosphere. This is grounded in the belief that employee commitment can predict organisational and individual outcomes, such as employee turnover, performance, and intention to stay in or leave an organisation. This study argues there is a strong perception that the leadership style has an impact on the performance of the school. From these 13 high schools, 184 teaching staff were selected to participate. These high schools were not performing above the provincial benchmark and teaching staff were selected to participate in this study because teaching is a core duty in this enterprise. The participants were selected conveniently; however, the sample was chosen in such a way that more participants were selected from the schools that were not performing above the provincial benchmark. A multi-factor leadership questionnaire was adopted and used to judge the response of the teaching staff. Overall results show that both transformational and transactional leadership have positive relationships with the organisational commitment. Another important discovery is that transformational leadership is used more than transactional leadership. There were some limitations that contributed to the opposing results in the study. This means that management, by exception passive, is playing a weak role in organisational commitment. The elements of the transformational leadership have consistent averages in the contribution of organisational commitment. In this study, teachers' perceptions about their own organisational commitment levels, and about school principals' leadership styles are analysed.
\end{abstract}

Keywords: Leadership style, Transformational Leader, Transactional leader, Commitment

\section{Introduction}

Today's changing milieu, challenges organisations on a regular basis to make strategic changes that will keep them up to date with the transforming atmosphere. An organisations has to ensure that it is up to date with the latest development and trend in the market; in doing so, leadership is regarded as the significant aspect to fulfill this process (Gul, Rehman, Rassaq, Ahmad \& Saif, 2012). This is grounded in the belief that employee commitment can predict organisational and individual outcomes, such as employee turnover, performance, and intention to stay in or leave an organisation (Yeh \& Chien 2012). Ultimately, the increased motivation and commitment to do the job will improve the employee's willingness to work harder, together with other employees, to achieve the organisational objectives. Organisational commitment can improve employee performance and the competitiveness of the organisation.

It is in this regard that the leadership theory suggests that a positive relation between transformation and transactional leadership, and other constructs such as commitment and job satisfactions, are important in any organisation. In the current context, transformation leadership could provide teaching staff with the upper hand, especially regarding their perceptions about their jobs. Thus, it is concluded that the leadership ability of a school principal plays a critical role in employee satisfaction and commitment; moreover, leaders could use various leadership styles to lead and direct their employee.

Common topics for discussions among managerial circles have always been leadership styles and their impact on 
the performance and effectiveness of the organisation. This study argues there is a strong perception that the leadership style has an impact on the performance of the school.

\section{Literature Review}

A review of the literature will focus on the two leadership styles, transformational leadership and transactional leadership, in an attempt to formulate a theory that will underpin the current study.

\subsection{Transformational Leadership}

Transformational leadership is defined as finding the current energy in the followers by creating an active environment in the organisation and mobilising this energy in the direction of the organisation's objectives (Cemaloglu, Sezgin \& Kiling 2012). Furthermore, Gul, Rehman, Rassaq, Ahmad \& Saif (2012) describes leadership as a process of motivating subordinates in fulfilling their self-interest in order to achieve the organisation's goals and pursue new directions for success. It is the role of the transformational leader to create a new vision and direction for the organisational renewal. The principal in the schooling system is expected to construct a roadmap leading towards better scholastic performance, and ensure that all teaching staff shares the same vision with the leader.

This type of leadership, portrayed in the abovementioned paragraph, will pull and direct the teaching staff intrinsically towards the achievement of the scholastic target set by the school. This style of leadership changes the perception and beliefs of the teaching staff to enhance their involvement and commitment in the organisational achievement (Bass, Avolio, Jung \& Berson 2003). Transformational leaders affect the teaching staff in such a way that they develop trust, promote admiration towards leadership, and exhibit loyalty to the organisation (Mester, Visser, Roodt \& Kellerman 2003). Mester et al. (2003) argue that they have found a positive correlation between transformational leadership and how effective subordinates perceive leaders, how much effort they say they are willing to expend for the leader, how satisfied they are with the leader, and how well the subordinates perform, as per their rating by the leader.

Although, it cannot be confirmed, Bono and Judge (2003) argue that there is considerable association between organisational commitment and transformational leadership.

\subsection{Transactional leadership}

Transactional leader can be described as leadership that occurs when one person takes the initiative in making contact with the others for the purpose of exchanging ideas (Bass \& Avolio 1993). This type of leader motivates the staff by attracting or appealing to their self-interest, the focus is on rewards as an external motivating factor. In this case, performance and target are achieved through the use of rewards. This type of leader follows a standard and task-basedgoals (Rehman, Shareef, Mahmood \& Ishaque 2012).

Bass and Avolio (1993) suggest that transformational leaders influence the organisational commitment of followers, encouraging them to think critically by using novel approaches, involving them in the decision-making processes and inspiring loyalty, while recognising and appreciating the different needs of each follower to develop their personal potential. According to Bussing (2002), transformational leadership is an extension of transactional leadership and a leader may display various degrees of the transactional or transformational leadership style, depending on the situation. In addition, Farahani, Taghadosi and Behboudi (2011) suggest that transformational leadership is a strategic organisation development intervention, designed to enhance the impact of leadership on commitment. Committed employees, working in an environment of trust, flexibility, and empowerment, are expected to act in the best interests of an organisation.

Transactional leadership is an exchange relationship that involves the reward of effort, productivity and loyalty. Transformational leaders emphasise higher motive development, and arouse the motivation and positive emotions of followers by means of creating and representing an inspiring vision of the future (Bass \& Avolio 1993). Transformational leaders are those who motivate their followers to perform beyond expectation by raising the follower's confidence levels and providing support for developing to higher levels. Followers feel a greater degree of respect and trust for the leader. The backbone of this theory is that followers are more motivated to enhance their performance by transformational leadership rather than by transactional leadership (Bass \& Avolio 1993).

One of the most important aspects in dealing with the leadership is the personality attributes and traits of leaders is that the personality attributes and traits affect the behaviour of the individual leader (Ahmadi, Ahmadi \& Zohrabi 2012). 


\subsection{Organisational commitment}

The concept of organisational commitment has recently evolved in management, and attracts significant response in studying workplace behaviours and attitudes. According to Meyer and Allen (1991), as it is associated with two important organisational problems, one is employees intention to leave organisation, followed by the actual decision to quit the organisation (Allen, Meyer \& Smith 1993). Organisational commitment includes the employee's organisational loyalty, eagerness to be a part of the organisation, willingness to do his/her level best for the organisation, and the extent to which employees perceive organisational goals and values as their own. Organisational commitment is associated with a psychological condition of an employee's attachment with the organisation (Meyer, Allen \& Smith 1993). Furthermore, they describe affective commitment as, "when the employee identifies with a particular organisation and its goals in order to maintain membership to facilitate the goal" (Gul et al. 2012). In order to measure the organisational commitment they developed a scale, widely used in past studies for its measurement.

\section{Research Methodology}

\subsection{Participants}

The current study of principals, conducted among 13 high schools, views leadership style as an influencing factor in motivating and encouraging the teaching staff to perform better in their respective academic duties. From these 13 high schools, 184 teaching staff were selected to participate. These high schools were not performing above the provincial benchmark and teaching staff were selected to participate in this study because teaching is a core duty in this enterprise. The participants were selected conveniently; however, the sample was chosen in such a way that more participants were selected from the schools that were not performing above the provincial benchmark. From the total of 13 high schools, some have been performing below the 70 percent benchmark for the past three academic years. This, in principle, classifies them as perennial schools. The data was obtained from the schools and all teaching staff encouraged to complete the questionnaire. The sample size was 184 teaching staff and the response rate was 109 (59.2\%). This response rate is regarded as good; this good response rate can be attributed to the fact that the questionnaires were administered during schools hours, and the researcher, assisted by the school administrative clerks, administered the questionnaires.

\subsection{Data collection instrument}

Identifying similar phrases, relationships between themes, distinct differences between target blocks, and common selfadministered questionnaires containing structured items were applied. Items in the questionnaire focused on leadership styles and the role of the leaders in the schools in assisting and supporting teaching staff, as well as how best the principal is managing the school. Closed-ended questions helped in eliciting specific information, while the open-ended questions enabled the respondents to express their views freely, without restriction. In order to obtain a holistic view of the overall leadership style present in the schooling system, a multifactor leadership questionnaire (MLQ) was used. From the MLQ the researcher decided to use 12 items for the current study; these items were adapted from the original scale designed by Meyer et al. (1993). As the methodological paradigm applied in this research is survey methods, with the questionnaire constructed in the Likert-type approach ranging from one to five, the study may be classified as quantitative research.

\subsection{Procedure}

Permission to conduct the study was requested from, and granted by, the district management for the schools. The researcher personally administered questionnaires, with the assistance of the schools' administrative clerks, and the research support group collected completed questionnaires. Throughout the study, every effort was made to maintain high ethical standards. Anonymity and confidentiality were protected at all times, a thorough explanation in the form of a covering letter was provided to all participants, detailing the purpose of the study. Data analysis and interpretation were done using the interactive model of quantitative data analysis (McMillan \& Schumacher 2010), which first involved sorting or sifting through the data and sequences. 


\subsection{Data analyses}

After all the questionnaires had been returned, it was important that mass data collected should then be reduced to a format suitable for analysis. Therefore, the respondents' responses were coded according to the emerging themes using the Statistical Package for Social Sciences (SPSS) version 21 for Windows program. Data were analysed by descriptive statistics such as percentages, frequency, and Cronbach alpha coefficients to test, inter alia reliability, and to describe the impact and the leadership style in these schools.

\section{Results and Discussions}

The study comprised of 184 respondents of which 109 responses were received. The results obtained from the empirical study will now be discussed. These results will be discussed according to the emerging themes from the variables stated in the literature.

Table 1: Results for multi-leadership reliability statistics

\begin{tabular}{|c|c|c|}
\hline Cronbach's alpha & Cronbach's alpha based on standardised items & $\mathrm{N}$ of items \\
\hline .776 & .789 & 10 \\
\hline
\end{tabular}

The Cronbach alpha coefficient is typically equated with internal consistency (Nyengane 2007). The Cronbach alpha is interpreted as a coefficient alpha, and its value ranges from zero to one. Nyengane (2007) advises that when calculating Cronbach's reliability coefficient, reliabilities less than 0.6 are considered poor, reliabilities within the 0.7 range are considered acceptable, and those coefficients over 0.8 are considered good. For the purpose of the current study, the Cronbach alpha coefficient rate is reported in Table 1 as 0.789 .

Table 2: Provision of assistance in exchange for efforts

\begin{tabular}{|ll|c|c|c|c|}
\hline & & Frequency & Percent & Valid percent & Cumulative percent \\
\hline Valid & not at all & 19 & 10.3 & 17.4 & 17.4 \\
& once in a while & 11 & 6.0 & 10.1 & 27.5 \\
& Sometimes & 11 & 6.0 & 10.1 & 37.6 \\
& fairly often & 37 & 20.1 & 33.9 & 71.6 \\
& frequently if not always & 31 & 16.8 & 28.4 & 100.0 \\
& Total & 109 & 59.2 & 100.0 & \\
Missing & System & 75 & 40.8 & & \\
Total & 184 & 100.0 & & \\
\hline
\end{tabular}

From the table above it is clear that the school principals were providing guidance to their teaching staff in exchange for their efforts to perform their duties better. From 109 respondents 33.9 percent were fairly happy with the assistance provided by the principal, while 28.4 percent of the respondents were of the view that the principal always provide assistance. The remaining 17.4 percent responded that assistance is not provided at all. These respondents (17.4\%) felt that the principal does not support their effort at all, not even once in a while. Although the high percentage of respondents were positive about the support that the principals were affording, the 37.6 percent of respondents who are either provided assistance once in a while, sometimes, or not at all, were quite significant to demonstrate the leadership style of the principal.

Table 3: Failure to interfere until problems becomes serious

\begin{tabular}{|ll|c|c|c|c|}
\hline & & Frequency & Percent & Valid percent & Cumulative percent \\
\hline Valid & not at all & 8 & 4.3 & 7.3 & 7.3 \\
& once in a while & 9 & 4.9 & 8.3 & 15.6 \\
& Sometimes & 15 & 8.2 & 13.8 & 29.4 \\
& fairly often & 50 & 27.2 & 45.9 & 75.2 \\
& frequently if not always & 27 & 14.7 & 24.8 & 100.0 \\
& Total & 109 & 59.2 & 100.0 & \\
Missing & System & 75 & 40.8 & & \\
Total & & 184 & 100.0 & & \\
\hline
\end{tabular}


Problem solving is one of the skills that the leader must demonstrate at all times. It is also important for the leader to react promptly as the problems emerge, and restore a favourable atmosphere in the working environment. The table clearly demonstrate that 24.8 percent and 45.9 percent of the respondents felt that frequently, and fairly often, the principal fails to interfere and provide leadership when there are problems at school. The remaining 29.4 percent of the respondents were of the view that their principals intervene before the problem becomes serious. The majority of the respondents felt that the principal fails to solve the problem at the inception stage; they wait for the problem to be serious before attending to it. The respondents rated the leadership style of the principal negatively.

Table 4: Avoidance of getting involved when important issues arise

\begin{tabular}{|ll|c|c|c|c|}
\hline & Frequency & Percent & Valid percent & Cumulative percent \\
\hline Valid & not at all & 14 & 7.6 & 12.8 & 12.8 \\
& once in a while & 7 & 3.8 & 6.4 & 19.3 \\
& Sometimes & 18 & 9.8 & 16.5 & 35.8 \\
& fairly often & 31 & 16.8 & 28.4 & 64.2 \\
& frequently if not always & 39 & 21.2 & 35.8 & 100.0 \\
& Total & 109 & 59.2 & 100.0 & \\
Missing & System & 75 & 40.8 & & \\
Total & & 184 & 100.0 & & \\
\hline
\end{tabular}

Table 4 represents the involvement and decision making of the principals in important matters pertaining to the schools functionality. From the 109 respondents, 35.8 percent and 28.4 percent confirm that their principals are not actually getting involved in handling and dealing with more complex matters. While the remaining 35.8 percent of the respondents felt their principals are not really involved in the difficult matter that concerns the running of their respective schools.

Table 5: Absent when needed

\begin{tabular}{|ll|c|c|c|c|}
\hline & & Frequency & Percent & Valid percent & Cumulative percent \\
\hline Valid & not at all & 22 & 12.0 & 20.2 & 20.2 \\
& once in a while & 11 & 6.0 & 10.1 & 30.3 \\
& Sometimes & 9 & 4.9 & 8.3 & 38.5 \\
& fairly often & 28 & 15.2 & 25.7 & 64.2 \\
& frequently if not always & 38 & 20.7 & 34.9 & 99.1 \\
& 40 & 1 & .5 & .9 & 100.0 \\
& Total & 109 & 59.2 & 100.0 & \\
Missing & System & 75 & 40.8 & & \\
Total & 184 & 100.0 & & \\
\hline
\end{tabular}

Table 5 reveals that the principals are quite heavily involved as academic leaders. The majority of the respondents $(64.2 \%)$ from the teaching staff felt that the principals are quite involved when needed. In most cases, the principal is available when an urgent matter arises.

Table 6: Talking optimistically about future

\begin{tabular}{|ll|c|c|c|c|}
\hline & & Frequency & Percent & Valid percent & Cumulative percent \\
\hline Valid & not at all & 12 & 6.5 & 11.0 & 11.0 \\
& once in a while & 9 & 4.9 & 8.3 & 19.3 \\
& Sometimes & 21 & 11.4 & 19.3 & 38.5 \\
& fairly often & 32 & 17.4 & 29.4 & 67.9 \\
& frequently if not always & 35 & 19.0 & 32.1 & 100.0 \\
& Total & 109 & 59.2 & 100.0 & \\
Missing & System & 75 & 40.8 & & \\
Total & 184 & 100.0 & & \\
\hline
\end{tabular}

The principal perceives the strategic goal of the school as a cornerstone; 67.9 percent of the respondents felt that the 
principal is providing guidance relating to the school growth and future of the organisation. Mclaggan, Bezuidenhout and Botha (2013) argue that transformational leaders are more sensitive to their environment and will rather create a strategic goal for the subordinate to follow. In the case of the current study, the teaching staff confirms that the leader gives direction on the future direction of the school, and is optimistic about the future.

Table 7: Waiting for thing to go wrong before taking actions

\begin{tabular}{|ll|c|c|c|c|}
\hline & Frequency & Percent & Valid percent & Cumulative percent \\
\hline Valid & not at all & 15 & 8.2 & 13.8 & 13.8 \\
& once in a while & 9 & 4.9 & 8.3 & 22.0 \\
& Sometimes & 13 & 7.1 & 11.9 & 33.9 \\
& fairly often & 35 & 19.0 & 32.1 & 66.1 \\
& frequently if not always & 37 & 20.1 & 33.9 & 100.0 \\
& Total & 109 & 59.2 & 100.0 & \\
Missing & System & 75 & 40.8 & & \\
Total & & 184 & 100.0 & & \\
\hline
\end{tabular}

From the table it is clear that principal waits for things to be out of control before taking action. The majority of the respondents were of the view that their leaders were reactive in solving crucial matters, rather than being proactive. The principal perceives the strategic goal of the school; 67.9 percent of the respondents felt that the principal is disseminating the information that relates to the organisational future of the school, and how to move the school to the future. Mclaggan et al. (2013) argue that transformational leaders are more sensitive to their environment and will rather create a strategic goal for the subordinate to follow. In the case of the current study, the teaching staff confirm that the leader gives direction on the future direction of the school.

Table 8: Avoiding making decisions

\begin{tabular}{|ll|c|c|c|c|}
\hline & Frequency & Percent & Valid Percent & Cumulative Percent \\
\hline Valid & not at all & 14 & 7.6 & 12.8 & 12.8 \\
& once in a while & 13 & 7.1 & 11.9 & 24.8 \\
& Sometimes & 13 & 7.1 & 11.9 & 36.7 \\
& fairly often & 37 & 20.1 & 33.9 & 70.6 \\
& frequently if not always & 32 & 17.4 & 29.4 & 100.0 \\
& Total & 109 & 59.2 & 100.0 & \\
Missing & System & 75 & 40.8 & & \\
Total & & 184 & 100.0 & & \\
\hline
\end{tabular}

From the table above, it is clear that principals are reluctant to make unpopular decisions. In most cases, exemplary leadership is tested by the decisiveness pertaining to important decision. Although 33.9 percent of the respondents confirmed that their principals fairly often take decisions on crucial matters, 29.4 percent of the respondents were satisfied that their principals takes decisions as and when required. The table further reveal that 12.8 percent of the respondents felt that their principals fail to take a decision when required, while 11.9 percent responded that they take decision quickly once in a while, and 11.9 percent responded by stating that they take decisions sometimes on important matters, otherwise they leave the problem unresolved.

\section{Conclusion}

The overall statistical findings show a clear picture of the relationship and impact of leadership styles on organisational commitment and performance of the school. A multi-factor leadership questionnaire was adopted and used to judge the response of the teaching staff. Overall results show that both transformational and transactional leadership have positive relationships with the organisational commitment. Another important discovery is that transformational leadership is used more than transactional leadership. There were some limitations that contributed to the opposing results in the study. This means that management, by exception passive, is playing a weak role in organisational commitment. The elements of the transformational leadership have consistent averages in the contribution of organisational commitment. 
In this study, teachers' perceptions about their own organisational commitment levels, and about school principals' leadership styles are analysed. In addition, relationships between school principals' transformational and transactional leadership styles, and teachers' organisational commitment levels, became the subject of the research. This study, using leadership styles as the predictors of organisational commitment, has supported the argument that school principals' leadership styles is a meaningful construct for understanding and explaining teachers' organisational commitment in underperforming schools. It suggested that school principals prefer a transformational leadership style to a transactional leadership style, and that teachers' continuance commitment levels are higher than affective and normative commitment.

Significant relationships between school principals' leadership styles and teachers' organisational commitment levels were found. Chi, Tsai and Chang (2007) state that principals' being supportive and open to teachers are important for teachers' commitment to their schools. Therefore, principals who motivate teachers and pay attention to their voices may help teachers experience deeper affective contact with school. This finding is in line with the ideas of Cemaloglu et al. (1990) that the school principal is likely to create a climate of commitment. In another aspect, the school principals probably use rewards to make the school's educational setting more effective. However, there is very little difference in the contribution of all the elements of transformational leadership; this is the basic reason why transformational leadership leads to commitment as a whole.

The purpose of this study was to examine the relationship between school principals' transformational and transactional leadership styles, and the organisational commitment of teachers. Only the perceptions of teachers on their commitment and the school principal's leadership styles were examined. As a conclusion, the leadership styles (transformational and transactional) both have a positive impact and contribution to organisational commitment.

\section{Reference}

Ahmadi, A., Ahmadi, F \& Zohrabi, M. 2012. Effect of the Leadership Styles on the Organisational Commitment Given the Staff Personality Traits. Interdisciplinary Journal of Contemporary Research Business. 4(1): 247-263.

Bass, B.M., \& Avolio, B.J. 1993. Improving organizational effectiveness through transformational leadership. Thousand Oaks, CA: Sage.

Bass, B. M., Avolio, B. J., Jung, D. I., \& Berson, Y. 2003. Predicting unit performance by assessing transformational and transactional leadership. Journal of Applied Psychology, 88(2): 207-218.

Bono, J. and T. Judge, 2003. Self-concordance at work: toward understanding the motivational effects of transformational leadership. Academy of Management Journal, 46: 554-571.

Bussing A. 2002. Trust and Its Relationship to commitment and Involvement in work and Organizations. South African Journal of Industrial Psychology, 28(4): 36-42.

Cemaloglu, N., Sezgin, F. and Killing, A.C. 2012. Examining the Relationships between School Principals' Transformational and Transactional Leadership Styles and teachers Organisational Commitment. The Online Journal of New Horizons In Education, 2(2): 53-63.

Chi, H. K. Lan, C. H., \& Dorjgotov, B. 2012. The moderating effect of transformational leadership on knowledge management and organizational effectiveness. Social Behavior and Personality, 40(6), 1015-1024.

Chi, H. K., Tsai, H. P., \& Chang, P. F. 2007. Investigating the relationship among leadership styles, emotional intelligence and organization commitment on job performance: A study of salespeople in Thailand. The Journal of Human Resource and Adult Learning, 3(2), 199-212.

Farahani, M., Taghadosi, M., \& Behboudi, M 2011. An Exploration of the Relationship between transformational Leadership Organisational Commitment: The Moderating Effect of Emotional Intelligence: Case Study in Iran. International Business Research 4(4):211-218.

Gul, M., Rehman, K., Rassaq, Ahmad, M,. \& Saif, M 2012. Leadership, Citizenship Behavior, Performance and Organizational Commitment: the Mediating Role of Organizational Politics. World Applied Sciences Journal 19 (11): 1540-1552.

Mclaggan, E., Bezuidenhout, A., \& Botha , C.T. 2013. Leadership style and organisational commitment in the mining industry in Mpumalanga. South African Journal Human Resource Management, 11(1): 1-9.

Nyengane, M.H. 2007. The relationship between leadership style and employee commitment: An exploratory study in an electricity utility of South Africa. Unpublished MBA dissertation. Rhodes University, Grahamstown, South Africa.

Meyer, J.P. \& Allen, N.J. (1984). Testing the "side-bet theory" of organizational commitment: Some methodological considerations. Journal of Applied Psychology, 69(2): 372-378.

Meyer, J.P \& Allen, N.J. (1991). A three-component conceptualisation of organizational commitment. Human Resource Management Review, 1(3): 61-89.

Meyer, J.P, Allen, N.J. \& Gellatly, I.R. (1990). Affective and continuance commitment to the organization: evaluation of measures and analysis of concurrent and time-lagged relations. Journal of Applied Psychology, 75 (6), 710-720

Meyer, J.P, Allen, N.J. \& Smith, C.A. (1993). Commitment to organizations and occupations: extension and test of a three component conceptualization. Journal of Applied Psychology, 78 (4), 538-551.

Mester, C., Visser, D. \& Roodt G. 2003. Leadreship style and its relation to employee attitude and behaviour. South African Journal of 
Industrial Psychology, 29(2): 72-82.Rehman, S., McMillan, J.H. \& Schumacher, S. 2010. Research in Education. New York: Pearson Education, United States of America.

Shareef, A., Mahmood, A., and Ishaque, A 2012. Perceived Leadership styles and organisational commitment. Interdisciplinary Journal of Contemporary Research in Business 4(1):616-626.

Yeh, $\mathrm{H}$, and Chien, S 2012. The Mediating Effect of Organizational Commitment on Leadership Type and Job Performance The Journal of Human Resource and Adult Learning, 8(2):50-59. 